University of Windsor

Scholarship at UWindsor

1998

\title{
Young Men and Technology: Government Attempts to Create a "Modern" Fisheries Workforce in Newfoundland, 1949-1970
}

Miriam Wright

University of Windsor

Follow this and additional works at: https://scholar.uwindsor.ca/historypub

Part of the History Commons

\section{Recommended Citation}

Wright, Miriam. (1998). Young Men and Technology: Government Attempts to Create a "Modern" Fisheries Workforce in Newfoundland, 1949-1970. Labour / Le Travail, 42, 143-159.

https://scholar.uwindsor.ca/historypub/82

This Article is brought to you for free and open access by the Department of History at Scholarship at UWindsor. It has been accepted for inclusion in History Publications by an authorized administrator of Scholarship at UWindsor. For more information, please contact scholarship@uwindsor.ca. 

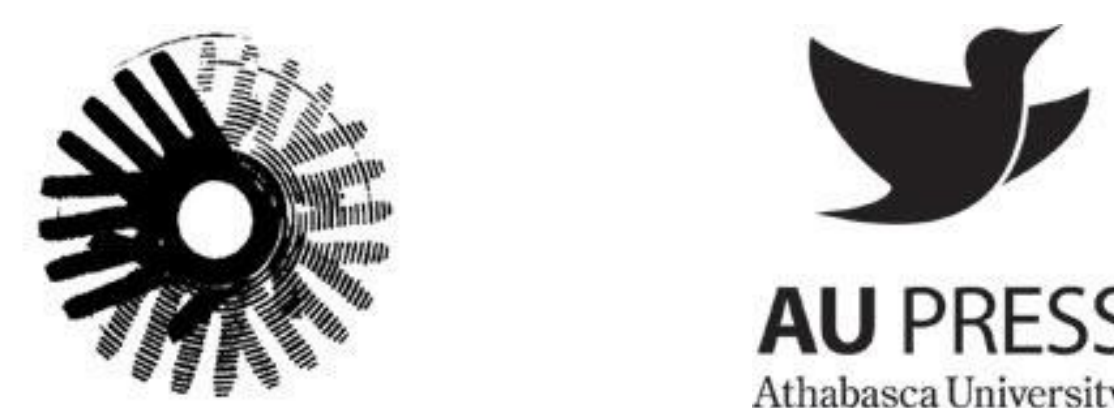

\section{AU PRESS}

Athabasca University

Young Men and Technology: Government Attempts to Create a "Modern" Fisheries

Workforce in Newfoundland, 1949-1970

Author(s): Miriam Wright

Source: Labour / Le Travail, Vol. 42, Masculinities and Working-Class History (Fall, 1998), pp. 143-159

Published by: Canadian Committee on Labour History and Athabasca University Press Stable URL: https://www.jstor.org/stable/25148883

Accessed: 27-02-2019 17:19 UTC

\section{REFERENCES}

Linked references are available on JSTOR for this article:

https://www.jstor.org/stable/25148883?seq=1\&cid=pdf-reference\#references_tab_contents You may need to $\log$ in to JSTOR to access the linked references.

JSTOR is a not-for-profit service that helps scholars, researchers, and students discover, use, and build upon a wide range of content in a trusted digital archive. We use information technology and tools to increase productivity and facilitate new forms of scholarship. For more information about JSTOR, please contact support@jstor.org.

Your use of the JSTOR archive indicates your acceptance of the Terms \& Conditions of Use, available at https://about.jstor.org/terms

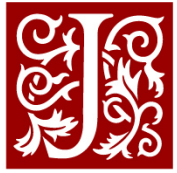

Canadian Committee on Labour History, Athabasca University Press are collaborating with JSTOR to digitize, preserve and extend access to Labour / Le Travail 


\title{
Young Men and Technology: Government Attempts to Create a "Modern" Fisheries Workforce in Newfoundland, 1949-1970
}

\author{
Miriam Wright
}

MAKING ONE'S LIVING from the sea is an occupation around which whole mythologies have grown. Popularized through songs, stories, and pictures, the "man of the sea" is a romanticized vision of the people who actually make their living fishing. It is a particularly masculine stereotype, depicting a world fraught with danger, hardship, and inhabited by strong, risk-taking men who were socially isolated and resistant to change. Despite the pervasiveness of this image, the reality of gender relations in present and historic fisheries is far more complex, mediated as it is through social and economic relations of work and society. With the advent of heightened levels of state intervention in fishing economies in the second half of the 20th century, state institutions, policies, and practices have also come to play a role in shaping and mediating gender relations.

This interplay of economy, state, and gender ideology has been explored in the Canadian context by scholars such as Jane Ursel and Ruth Roach Pierson. ${ }^{1}$ Ursel describes the increasing government intervention in the family which accompanied the development of an industrialized nation state as a transition from familial to social patriarchy. Pierson analyses the relationship between gender ideology and a specific area of state policy - Unemployment Insurance. Pierson found that a

${ }^{1}$ Jane Ursel, Private Lives, Public Policy: 100 Years of State Intervention in the Family (Toronto 1992); Ruth Roach Pierson, "Gender and the Unemployment Insurance Debates in Canada, 1934-1940," Labour/Le Travail, 25 (Spring 1990), 77-103; Ruth Roach Pierson, "They're Still Women After All": The Second World War and Canadian Womanhood (Toronto 1986).

Miriam Wright, "Young Men and Technology: Government Attempts to Create a 'Modern' Fisheries Workforce in Newfoundland, 1949-1970," Labour/Le Travail, 42 (Fall 1998), 143-59. 
hegemonic male breadwinner/female dependent gender ideology pervaded the debates and policies of Unemployment Insurance in the 1930s. When the programme was finally implemented the assumption that males were the only "legitimate" workers and family providers had an impact on men's and women's access to unemployment benefits. Pierson suggests that this ideology also informed Leonard Marsh's Report on Social Security for Canada, a document which many acknowledge as the blueprint for the welfare state in Canada. ${ }^{2}$

To understand something of the historic gender relations in the fishery, we need to have a broader knowledge of the changes that were occurring in the economy, as well as an awareness of how a specific gender ideology was part of the fabric of the state's modernization plans. In the years following World War II, the Newfoundland fishing economy was transformed from a predominantly inshore, household-based, saltfish-producing enterprise into an industrialized economy dominated by vertically-integrated frozen fish companies. ${ }^{3}$ This transition was initially fueled by larger changes in capital, markets and technology taking place at the international level, particularly in the United States where quick freezing had been pioneered by large companies such as Birdseye (General Seafoods-General Foods), Booth Fisheries and Gorton-Pew. In the post-war period, the United States became the primary market for frozen fish and Newfoundland was a major supplier. Early in this transition, the state became involved in supporting this new industry - first the Commission of Government that ruled Newfoundland from 1934 to 1949 , then the Canadian federal government, as well as the new provincial administration headed by Premier Joseph Smallwood after Newfoundland joined Confederation. These various levels of the state were involved in financing and supporting this transformation, largely through loans to private frozen fish firms, vessel and gear development projects and through educational training programmes for people in the fishery. Although the state was not united in its methods of assisting the fishery, ${ }^{4}$ both federal and provincial governments generally promoted the idea of a centralized, industrialized and "modernized" fishery.

The state was far from gender-neutral in these interventions and played a role in mediating, and sometimes shaping, gender relations in the fishery. Although some authors have begun to look at the state and women in the fishery in this period, ${ }^{5}$

${ }^{2}$ Leonard Marsh, Report on Social Security for Canada 1943 (Toronto 1975).

${ }^{3}$ Miriam Wright, "Newfoundland and Canada: The Evolution of Fisheries Development Policies, 1940-1966," PhD thesis, Memorial University of Newfoundland, 1997.

${ }^{4}$ Wright, "Newfoundland and Canada," chapters Three and Four. The provincial government provided direct assistance to private enterprise through loans from 1949 to 1966, whereas the federal government preferred more generalized support through public works projects, experimental gear and fishing programs, and educational training.

${ }^{5}$ Patricia M. Connelly and Martha MacDonald, "State Policy, the Household and Women's Work in the Fishery," Journal of Canadian Studies, 26, 4 (1991-92), 18-32; Barbara Neis, "From 'Shipped Girls' to 'Brides of the State': The Transition from Familial to Social Patriarchy in the Newfoundland Fishing Industry," Canadian Journal of Regional Science, 
relatively little is known about how the state perceived men and their place in the "modern" fishery. For our purposes, the male breadwinner ideology which Pierson found in the Unemployment Insurance debates may have some relevance for a study of state economic policies and the Newfoundland fishery. British historian Keith McClelland has associated the rise of this ideology with the growth of the industrial economy. ${ }^{6}$ Although working class women were an integral part of the labour force from the beginning of the industrial revolution, middle class reformers and male working class trade unions began promoting the middle class domestic ideal in the latter years of the 19th century. Just as the model of the male as the sole family income-earner was a later development in the industrialization process in Britain and North America, this concept was a relatively recent development in Newfoundland. The male breadwinner ideology, which assumed the primacy of male labour, had not previously been a part of the gender relations in outport Newfoundland.

Historically, Newfoundland's gendered division of labour arose out of the needs of the inshore resident fishery and the production of dry salted-codfish known as "shore cure," a product highly valued in the markets of southern Europe. ${ }^{7}$ In the Newfoundland inshore fishery, saltfish was produced through the efforts of the entire family. Men, for the most part, caught the fish using small boats and gear such as handlines and cod traps, while the shore crew (consisting of wives, daughters, sisters and younger sons), would help split and salt the fish. ${ }^{8}$ The women would then take the salted fish and spread them onto wooden fish flakes, or racks, to dry in the sun for a week or so until cured. The women tended the fish, taking it in each night, or during inclement weather. Besides curing the fish, women also provided the basic needs of the family by gardening, preserving food and making clothing. As the transition to an industrialized fishery occurred, however, state planners and the policies they created suggested that women would have a minimal role in the economy and that men should shoulder a larger share of the responsibility for providing for the family. This paper will argue that the male bread-winner model, the dominant gender ideology of western culture (but not of Newfoundland

16, 2(1993), 185-211; Miriam Wright, "Women, Men and the Modern Fishery: Images of Gender in Government Plans for the Canadian Atlantic Fisheries," in C. McGrath, B. Neis, M. Porter, eds., Their Lives and Times: Women in Newfoundland and Labrador (St. John's 1995).

${ }^{6}$ Keith McClelland, "Masculinity and the 'Representative Artisan' in Britain 1850-1880," in Michael Roper and John Tosh, eds., Manful Assertions: Masculinities in Britain since 1800 (London 1991).

${ }^{7}$ See Hilda Chaulk Murray, More Than 50\%: A Woman's Life in a Newfoundland Outport, 1900-1950 (St. John's 1979); Marilyn Porter, “'She Was Skipper of the Shore Crew': Notes on the History of the Sexual Division of Labour in Newfoundland," Labour/Le Travail, 15 (Spring 1985), 105-23.

${ }^{8}$ These gender divisions were flexible, at times. Men sometimes helped with the shore work, while women very occasionally fished. Historically, women also worked as cooks on the Labrador schooners, vessels outfitted to fish in the summer months off the Labrador coast. 
outport culture at the time), was embedded in state economic policies for the Newfoundland fishery in the post-World War Il period.

The state's plans for the transformation of the Newfoundland fishery workforce was tied to its plans for "modernizing" the fishery itself. Technology was seen as the key to improving the fishery and the introduction of offshore trawlers, "near-shore" longliners, new gear types, and electronic sounding equipment was part of the larger plan to industrialize the fishery. State planners, however, believed that the men who worked in the Newfoundland fishery needed to be transformed so they could be integrated into the new fishing economy. Fishers were expected to drop their older fishing methods, outlooks, and patterns of occupational pluralism and become "professional" harvesters and processors.

By the 1960s, government training programmes increasingly focused on encouraging young men to work on offshore trawlers. The intensification of offshore fishing by foreign countries in this period, and the demands of the government-funded frozen fish companies for greater quantities of fish, led the federal government to assist in the development of Canada's deepsea fleet. Despite state efforts, however, the difficult working conditions and poor remuneration for trawler crews ensured that the young men in question were reluctant to follow the career path the state encouraged them to take. Although the attempts to recruit young men as trawler crews were not entirely successful, this and the other examples of the government's mediating role helps illustrate the complexity of economy, state and gender ideology all involved in the construction of a new fisheries workforce.

\section{State Planners' Reactions to the Gendered Division of Labour in the Household Fishery}

AS GOVERNMENT OFFICIALS turned their attentions to the fishery in the 1940s and early 1950s, they began expressing dismay at the existing gender division of labour in the inshore fishery. For the most part, both federal and provincial planners found women's involvement in the household fishery to be anachronistic - a sign that the Newfoundland fishing economy was at a delayed state of development. A provincial Department of Fisheries official, H.C. Winsor, deplored the sight of the outport "woman of 30 who looks 60 with thick ankles, bent back and lined face." The effects of the weather and physical labour, considered "rugged" in a man, were unseemly in a woman. A prevalent theme in the early discussions of the rural economy was the need to eradicate the dependence on female labour.

A federal Department of Fisheries employee, W.F. Doucet, who surveyed the province in 1952 as part of a team investigating the fishery, wondered at the lack of distinction between "public" and "private" in the inshore fishery. The foundation

${ }^{9}$ Provincial Archives of Newfoundland and Labrador (hereafter PANL), GN 34/2, file Newfoundland Fisheries Development Authority (hereafter NFDA) H.C. Winsor, H.C. Winsor to Edwin Burdell, 4 August 1958. 
of the male breadwinner/female dependent gender ideology is the assumption that men and women inhabit separate spheres. Men belong to the public world of politics and commerce, while women inhabit the private realm of home and family. Doucet was struck, not only by the different division of labour in this economy, but also the unity of home and workplace. He remarked:

In these and a few other settlements one is arrested by the cohesiveness of the family and the extent to which the fishery is a family endeavour. The stores, the flakes and the home are one unit. Men catch the fish and women make or cure it. ${ }^{10}$

The fact that Doucet would remark on the nature of the family fishery and women's role within it suggests that this society had a different set of expectations about the roles of men and women from his own. He noted:

I was happy to see that in relatively few communities is this way of life accepted with passive resignation. Women are gradually "wisening up," probably a direct result of the radio and the movie projector, and are beginning to rebel against their enslavement to the fish flake. This may indicate the dawn of a new era. ${ }^{11}$

Doucet suggested that North American culture, through radio and movies, was leading women to aspire to more purely domestic pursuits. By becoming aware of North American social norms, where the male breadwinner/female dependent model was more dominant, women supposedly would wish to adopt the new culture. In expressing these views, the fisheries planners were trying to impose the hegemonic gender ideology of male breadwinner/female dependent on a society with different gender roles.

The issue of women's participation in the rural economy arose in the first major investigation into the Newfoundland fishery after Confederation. The Report of the Newfoundland Fisheries Development Committee of 1953, the work of a group of federal and provincial government representatives, recommended centralization of production through government-supported frozen fish and saltfish plants, the introduction of new technology, as well as small-scale community development. ${ }^{12}$ In addition, the report suggested that in the "modern" fishery, men would be the primary breadwinners. The report applauded the removal of women from the fishery, saying it would "allow them to devote their time to their household duties

\footnotetext{
${ }^{10}$ National Archives of Canada (hereafter NAC), RG 23, v. 1749, file 794-17-1 [4], W.F. Doucet to I.S. McArthur, Markets and Economics Service, 6 August 1952.

${ }^{11}$ NAC, RG 23, v. 1749, file 794-17-1 [4], W.F. Doucet to I.S. McArthur, Markets and Economics Service, 6 August 1952.

${ }^{12}$ Newfoundland and Canada, Report of the Newfoundland Fisheries Development Committee (St. John's 1953).
} 
and to live in an atmosphere of human dignity as wives and mothers."13 Women, it was suggested, did not belong in the market economy and should leave to fulfil their "natural" roles as dependent wives and mothers. Conversely, men would have to take care of their women and not depend directly on their labour to produce fish for market.

Despite the assertions of these government officials, however, the gradual withdrawal of women from fish curing had more to do with economics than American movies. In the 1950 s, the rise of the frozen fish industry meant that women's shore work was no longer required to the same extent. After women stopped making shore cure, however, few could afford to depend solely on the labour of their husbands. Many women moved into jobs at the frozen fish processing plants that were built on the island during this period. By the 1980 s, women made up 50 per cent of the workforce in those plants, but remained for the most part in the lowest paying jobs in positions deemed "unskilled" such as packing and trimming. 14

\section{Male Breadwinner Ideology and Fisheries Policies}

THE BELIEF of fisheries planners that women would leave the fishery was tied to their assumption that men would become the primary breadwinners for their families. This tranformation of men into sole family income earners, however, was tied to the broader plan to replace the saltfish industry with the frozen fish industry, and to replace the rural household system with the relations of production and consumption of an industrial society. This meant encouraging men to learn to operate the new technology of the modern fishery, as well as giving them skills to allow them to earn more money to make up for the loss of the economic activities of the other family members. Providing men with skills and technological training was considered crucial to enable them to increase their fishing efficiency, raise their productivity, and increase their incomes. With their higher incomes, fishing families could purchase items for their daily needs, rather than relying on the labour of all family members. "Professionalization" of fishers, meaning that men would become more specialized in their skills and activities so that they would spend more of their time fishing was one of the major themes in the Newfoundland educational programmes. No longer would the fisher be a "jack-of-all-trades," as the Newfoundland Director of Fisheries Training described them, but the bearer of highly specialized technical knowledge. ${ }^{15}$ Creating a new fisheries workforce, then,

${ }^{13}$ Newfoundland and Canada, Report of the Newfoundland Fisheries Development Committee, 102.

${ }^{14}$ Susan Williams, Our Lives are at Stake: Women and the Fishery Crisis in Newfoundland and Labrador (St. John's 1996); Fishery Research Group, The Social Impact of Technological Change in Newfoundland's Deepsea Fishery (St. John's 1986).

${ }^{15}$ PANL, GN 66/2/C, file Annual and Periodic Reports on Progress of Fisheries Training Programme, "Fisheries Training Progress in Newfoundland" by R.H. Squires, 29 October 1956. 
encompassed both the explicit needs of a modern, industrial society (a technologically-trained workforce) and the implicit belief that males, in their new roles as family primary family breadwinners, would fulfil those needs.

Several fisheries income support programmes of the period reveal the inherent assumption that males were the main income-earners for the family. In 1957, a new Unemployment Insurance programme for fishers and other seasonal workers was created. For the first time, fishers, working either singly or in fishing crews, would receive benefits based on their sales of fresh or salted fish to registered buyers. The male breadwinner model which Pierson argued permeated earlier Unemployment Insurance debates was inherent in the new programme for fishers. Women were explicitly excluded from making contributions or receiving benefits if they were married to any member of the fishing crew. ${ }^{16}$ If married women did work as members of the crew, their shares were attributed to their husbands. Since most fishing crews were comprised of family members, this effectively proscribed wives' direct involvement in fishing operations, either through working on the boat, or curing the catch on shore. Implied in this policy is the assumption that the labour, and the fruits thereof, belonged to the men, not the women. Men, according to the Unemployment Insurance programme, were workers and should be rewarded as such. Women should be discouraged from working, but if they did, their labour was considered property of the male head of household.

The male breadwinner model was further strengthened by the practice of issuing social benefits of various kinds based on the marital status of the fisher. Unemployment insurance benefits, for example, were slightly higher for those fishers with dependents than those who were single. ${ }^{17}$ An emergency assistance programme for those experiencing a catch failure in the inshore fishery in 1965 also made similar distinctions. Fishers short of qualifying insurable weeks received a flat rate of $\$ 200$ that winter if they were single and $\$ 350$ if they were married. ${ }^{18}$ Training programmes organized by the provincial Department of Fisheries in the 1950 s and early 1960s, but partially funded through the federal Department of Labour also provided separate daily allowances for single and married men while they were participating in the courses. ${ }^{19}$ No such programmes of financial assistance were extended to the female members of the workforce.

${ }^{16}$ PANL, GN 34/2, file NFDA Unemployment Insurance, "Changes in Unemployment Insurance Regulations Applicable to Fishermen," Ottawa, November 1958.

${ }^{17}$ NAC, RG 23, v. 1137, file 721-64-3 [4], "Fisherman's Handbook on Unemployment Insurance, First Edition," Ottawa: Unemployment Insurance Commission, no date.

${ }^{18}$ PANL, GN 34/2, file 11/4/16.2 vol. 1, Federal Department of Fisheries Press Release, 15 January 1966.

${ }^{19}$ PANL, GN 34/2, file 214/15 vol. 1, Administrative Assistant to R.H. Squires, Director of Vocational Training, 1 April 1959. 


\section{Training Young Men for the Modern Fishery}

APART FROM INCOME support initiatives, both federal and provincial governments were involved in establishing various technological training programmes. Technology has long been seen in western culture as a "masculine" domain, and male workers attempts to control the introduction of new technology into the workforce has been a prevalent theme in recent studies of the gendered labour process. ${ }^{20}$ Unlike some of the more traditional trades where workplace skills were transmitted from worker to worker or through experience, the skills needed to operate offshore vessels and processing plant machinery were new. There were some concerns, however, about the efficacy of educating older men, partly because of the relatively high illiteracy rate among outport fishers, and partly because of a presumed reluctance on the part of the fishers to try new methods. ${ }^{21}$ W.C. MacKenzie, for example, complained about how the "deep-seated resistance to change" among the inshore fishers hampered efforts to decrease dependence on small boat fishing. ${ }^{22}$ Young men, believed to be more adaptable to modern ways, became the focus of the fisheries training programmes. Pervasive was the idea that the new young men of the fisheries would have to be fundamentally different from their fathers. In fact, the planners believed that technical training in an institution would soon replace the "traditional" forms of fisheries knowledge passed down from fathers to sons.

Not only would they have to learn new skills, but the young men would have to adopt a "modern" spirit, a mind-set conducive to technological change. In 1954, Robert Hart, the chief supervisor of the Industrial Development Service in the federal Department of Fisheries, discussed the merits of training programmes. He argued, "I can think of no more worthy cause ... than in preparing the minds of the young men in Newfoundland to cope with an advancing fisheries development programme." ${ }^{, 3}$ Such a programme, he claimed, would only be effective if the courses helped "create a new concept in their minds," along with the practical skills they would gain.

This attitude can also be found in an earlier report written by federal Deputy Minister of Fisheries, Stewart Bates, for Nova Scotia. Bates declared that technical training was crucial to develop the "desired habits of mind." ${ }^{24}$ The Report of the Newfoundland Fisheries Development Committee also contained references to the need to develop a progressive frame of mind, and specifically an "industrial

${ }^{20}$ See Ava Baron, ed., Work Engendered: Toward a New History of American Labor (Ithaca 1991).

${ }^{21}$ PANL, GN 34/2, file 11/80/7, ARDA Study No. 1024 —"Education" by D.L. Cooper, 3 September 1964.

${ }^{22}$ NAC, RG 23, v. 1751, file 794-17-1 [14], W.C. MacKenzie to Deputy Minister of Fisheries, no date.

${ }^{23}$ NAC, RG 23, v. 1751, file 794-17-7 [1], Robert Hart, chief supervisor, Industrial Development Service, to Otto Young, Fisheries Research Board, 29 May 1954.

${ }^{24}$ Stewart Bates, The Report on the Canadian Atlantic Sea-Fishery (Halifax 1944), 22. 
discipline" among the workers. ${ }^{25}$ Not only would the young men of the modern fishery workforce be capable, technically skilled breadwinners, they would also be accepting of North American values and way of life.

Although federal officials sometimes spoke about the need to educate the young men, it was Premier Joseph R. Smallwood who "adopted the cause." In 1962 he called a fisheries conference and invited fishers, plant owners, government officials, and others connected to the fishery. The fishers themselves talked mainly about their concerns for obtaining better prices, problems with securing bait, the lack of funds for improving their equipment, and the threat posed by foreign fishing trawlers. In his final address, Smallwood acknowledged these issues, yet chose to single out the problem of unemployed young men and declared it to be the single gravest crisis facing the Newfoundland fishery. "These young men," he told the crowd,

around our outports today are the blood and brawn that built the British Empire. They can very quickly go to seed ... if they are allowed to degenerate into cigarette smoking, loungers and loafers hanging around the rocks, living partly on the dole ... without any real driving ambition to work. ${ }^{26}$

Just as Pierson found that unemployment was seen as a "man's" problem, Smallwood, too was concerned that young men would not find their place in society as workers.

Smallwood believed that technology was the key to attracting young men to the fishery. "If they're going back into the fishery, that fishery has to be a far more up-to-date thing, a far more modern thing." ${ }^{27}$ Smallwood was widely known for his ability to pull the rhetorical strings to political advantage, and his campaign for educating the young men in Newfoundland was partly related to his attempts to retrench popular support after some setbacks in the $1950 \mathrm{~s}^{28}$ Nevertheless, significant is Smallwood's emphasis on the need to shape this valuable resource, the young men of Newfoundland into the workforce of the future. Both the young men and the fishery needed to be transformed, introduced to the industrial age, and together they would build a new North American industrial society in Newfoundland.

${ }^{25}$ Newfoundland and Canada, Report of the Newfoundland Fisheries Development Committee, 72.

${ }^{26}$ PANL, MG 644, file 287, "Proceedings, Fisheries Convention, September 27, 1962," 4-5. ${ }^{27}$ PANL, MG 644, file 287, "Proceedings, Fisheries Convention, September 27, 1962," 5.

${ }^{28}$ In the 1950s, several of Smallwood's key cabinet ministers left politics in opposition to Smallwood's policies. Also, Smallwood's actions in decertifying the International Wood Workers of America union during the 1959 loggers' strike were the target of much criticism both within and outside the province. See Richard Gwyn, Smallwood, the Unlikely Revolutionary (Toronto 1972). 
The emphasis on young men and technology as the perfect partnership for the modern fishery was embodied in the College of Fisheries, Navigation, Marine Engineering and Electronics, which opened in St. John's in 1964. Of the five general streams of study offered, three were directly related to crewing or maintaining offshore fishing vessels - Nautical Science, Mechanical Engineering, and Electrical Engineering. The others included Naval Architecture, which provided training in shipbuilding and design, and the Department of Food Technology which organized in-plant training programmes for fish processing plant employees.

The overwhelming focus of the College of Fisheries, in its early years, however, was training young men to work as trawler crews. Trawler technology was considered essential for the development of the frozen fish industry in Newfoundland in the first fifteen years after confederation. The frozen fish industry was relatively new to the province, with a half dozen small companies having been established during World War II. Through loan assistance from the provincial government, these vertically integrated companies were able to expand their operations and build more frozen fish plants around the island. This made them, however, heavily dependent on trawlers to obtain a sufficient supply of fish to keep the plants operating at full capacity throughout the year.

Getting young men to join the trawler crews was an integral part of the company owners' plans to make their businesses viable. They always assumed, however, that the new trawler workforce would be male. In the pre-confederation fishery, men had done most of the harvesting, with women only rarely going out on the water. Government and industry people alike assumed that this gender division of labour would continue into the modern era. Also, the unique workplace conditions of offshore trawler work meant that the people who worked together also had to live together during the voyages. The company owners wanted technologically-trained, physically strong workers, all of the same gender. Although in the years that followed, many women began fishing on inshore vessels, the offshore trawler work environments remained exclusively male. ${ }^{29}$

The College of Fisheries, represented a new era - not only a new industrial fishery, but also a new way of acquiring knowledge and skills apart from the traditions of their fathers. It represented a break from the past and a panacea for the problems of the Newfoundland fishery. Knowledge would no longer be passed from father to son, but from technological expert to student within an institutional setting provided by the state. An unbounded faith in the ability of "technological man" to solve the problems of the world was behind this approach to industrializing the fishery. In the process, the young men would be moulded into technologicallytrained, family breadwinners.

${ }^{29}$ According to the Canada 1991 Census, women comprised 10 per cent of inshore fishers, but none of the offshore trawler workers. The large factory freezer trawlers of the former Soviet Union, which began fishing in the waters off the coast of Newfoundland in the 1960s, did have female workers aboard. 
The enthusiasm with which various government planners greeted the opening of the College displayed the hope placed in this new direction. A scientist with the Fisheries Research Board, C.H. Castell, who was invited to attend the opening ceremonies, remarked how Smallwood had effectively orchestrated the event to put the young men front and centre. ${ }^{30}$ Noting that Smallwood was a "past-master of a showman," Castell claimed the ceremony was replete with such dignitaries as members of the provincial cabinet, the Chief Justice, and members of the staff of the college sitting on the stage. The front rows of the hall were left empty.

After some stirring music by a local choir of folk singers the 150 young men, dressed in their black sweaters, bright crests and gray trousers, marched in. They looked wonderful and behaved themselves well. ${ }^{31}$

According to Castell, Smallwood made a point of emphasizing that Newfoundland was taking a step into the future by training these young men in the latest fisheries technology. As Castell noted, however, the college was far from prepared for the new students at that point, with only a few instructors appointed or classes organized.

Smallwood's enthusiasm about the young men and technology, and the hopes for a better way of life, was echoed by other fisheries officials. Dr. D.L. Cooper, who was employed by the provincial Department of Fisheries, argued in a report for the Atlantic Rural Development Agency that:

... the hope of a bright future in the fishery lies in the young men, those still in school, those who will enter school, those young enough and with sufficient basic education to undergo a rigorous upgrading to the normal standard required for technical education in a profession that is developing with such speed. ${ }^{32}$

Likewise, in an article in the federal fisheries publication, Fisheries of Canada, enthused about the presence of the young men at the College of Fisheries, and the promise they held for a highly developed fishery. "Among the students," the article claimed,

are tomorrow's skippers and mates of the streamlined and efficient sea-going fishing vessels: the marine engineers who will operate engine rooms grown highly sophisticated in a world of advancing technology. ${ }^{33}$

\footnotetext{
${ }^{30}$ NAC, RG 23, Accession 90-91/230, Box 10, file 711-29-7 [1], "Impressions of the Newfoundland School of Fisheries" by C.H. Castell, 5 March 1964.

${ }^{31}$ NAC, RG 23, Accession 90-91/230, Box 10, file 711-29-7 [1], "Impressions of the Newfoundland School of Fisheries" by C.H. Castell, 5 March 1964.

${ }^{32}$ PANL, GN 34/2, file 11/80/7, ARDA Study No. 1024, 3 September 1964.

${ }^{33}$ Fisheries of Canada, 19, 9 (March 1967), 4.
} 
The future would be a world of advancing technology, guided, and controlled by the trained, knowledgeable young men building a better way of life. Implicit was the belief that these young men would no longer have to rely on the labour of their wives to make a living.

\section{Policy into Practice \\ The Difficulties of Securing Offshore Trawler Workers}

TRANSLATING those visions of the new industrial society and the men who would develop it into practice, however, proved to be a challenge. Young men did not flock to the trawler jobs as both government officials and company owners had expected. Amid all the enthusiasm about technology bringing with it a better life, those promoting the offshore fishery did not seem to realize the significance of the profound workplace changes. Unlike the inshore fishery, trawler crews went to sea for up to ten days at a time, where they were expected to operate the trawls, and to split and ice the catch. The work was tiring and dangerous, particularly on the older side trawlers that were in use by the companies in the 1960s. Living conditions were cramped, and unlike other industrial workers, the trawler crews could not go home after their shifts were finished. Most trawler workers would only see their families once or twice a month, when the ship made a one or two-day stopover in port to unload the catch and obtain supplies. Stress on family life was considerable, as the spouses remaining at home were left with the task of caring for children or aging parents. The men working on the offshore trawlers had to live without daily contact with relatives and friends. ${ }^{34}$

Besides the difficult working conditions, until the mid-1970s, there were no guaranteed wages for trawler crews. At one level, the offshore fishery was industrialized, in that the trawlers were owned by vertically-integrated fishing companies, which controlled the harvesting, processing and marketing of fishery products. Yet, the company-crew relations had not yet made the transition to an industrial relationship. Vestiges of an older payment arrangement traditionally used in the Newfoundland Banks fishery, a deepsea, schooner/dory fishery which had declined by the mid-20th century, appeared in the new offshore trawler fishery. In the Banks fishery, as in the trawler fishery, the people who fished on these vessels received a share of the catch, rather than a guaranteed wage. Typically, the company which owned the boat received one share, the captain another, and the crew divided the remaining share. If the catch was poor, instead of taking home money, the crew might end up owing the company money for food. Instead of being considered company employees, the trawler workers were designated "co-adventurers." The term was ironic, however, as it implied the workers had some stake in the enterprise. Trawler workers did not have shares in the vessel or the company, and had very little control over their working lives. Factors such as the type, size, age, and

${ }^{34}$ Fisheries Research Group, The Social Impact, 171-204. 
condition of the vessel itself, as well as the skills of the captain, greatly affected the ability of the trawler crews to make a catch that would produce good returns. According to a study on working conditions in the offshore industry, trawler crews in the 1960s did not even have formal, signed contracts with vessel owners - they simply showed up at the port when it was time to embark on a fishing trip. ${ }^{35}$ Despite the mythology of the fisherman as a risk-taker, the young men of Newfoundland, for the most part, were unwilling to take the kind of gamble that was offered by the large fishing companies. Clearly, the transition from a rural, household economy to an industrial economy was not smooth. The fact that young men for the most part resisted the government's attempts to recruit them indicates that transforming the social and economic relations of the fishery, and changing the way that men worked and lived was not uncontested.

Indeed, working on a trawler was considered a job of last resort by young men in the 1960s and early 1970s, and the men showed it by the extremely high turnover rate for trawler crews, and the companies had difficulty in attracting, and keeping workers. John Proskie, an economist with the federal Department of Fisheries, studied nine trawlers in $1966 .{ }^{36}$ Of the nine vessels he studied, three were 120 -foot trawlers and six were 130-foot trawlers. Most vessels sailed short-handed, as only 7.6 per cent of the trips for the 120 -foot ships and 4.7 per cent of the trips for the 130-foot ships were made with a full crew of fourteen and sixteen respectively. Indications of the high turnover rate can be found in the statistics relating to the total number of men employed on these vessels over the course of one year. The three 120-foot vessels which had positions for a total of 42 workers actually employed 84 different men in 1966. Likewise, the six 130-foot boats with positions available for 96 men employed 277 men. According to another study on working conditions in the offshore fishery, most of the men who worked on trawlers in the period from $1956-1968$ only did so casually, or part-time. ${ }^{37}$ The fact that jobs were plentiful in other parts of Canada at that time also contributed to the high turnover rate.

Not only did fisheries planners underestimate the young men's lack of enthusiasm for the jobs in the newly-industrialized sector of the fishery, the expected move of people from the inshore to the offshore fishery did not occur. In fact, there were indications that many of the men who did take jobs on the trawlers were most likely not sons of inshore fishers. No complete demographic study of trawler crews of the 1960s has been done, but evidence suggests that there may have been a connection between the 1960s trawler crews and the older Banks fishery. The Banks fishery was concentrated in a few communities such as Grand Bank, Burin and Harbour Breton. Although they fished from schooners equipped with dories rather than from other trawlers, the men of the Banks fishery were accustomed to

\footnotetext{
${ }^{35}$ Fisheries Research Group, The Social Impact, 171-204.

${ }^{36}$ Fisheries of Canada, 20, 8(1968), 13-9.

${ }^{37}$ Fisheries Research Group, The Social Impact, 171-204.
} 
working on the high seas for weeks at a time. When the Banks fishery declined in the 1940s, many of the younger men of those communities left to obtain jobs in the offshore fishery of Nova Scotia. Others, however, remained and worked in the growing offshore fishery controlled by the frozen fish companies. A report from the Newfoundland Frozen Fish Trades Association on training of trawler crews claimed that many of their trawler workers were older men who had formerly worked in the Banks fishery. ${ }^{38}$ As well, a survey done in 1967 found that the majority of trawler workers came from families where one or more male relatives had also worked on trawlers, suggesting that recruitment occurred through families and community ties. ${ }^{39}$ If, as this preliminary evidence indicates, there was a connection between the Banks communities and the new offshore trawler fishery, this raises a number of questions about recruitment patterns, and attachments to the offshore fishery. How many of the young men who went through the College of Fisheries programmes remained in the offshore sector, and for how long, as opposed to those with connections to the Banks fishery? Did a familiarity with an offshore fishery, albeit of a rather different kind, make for an easier transition to life on the trawlers? These and other questions about the impact of fisheries development on Newfoundland fishers remain.

One of the foundations of the industrial development project, the steady integration of Newfoundland men into the offshore fishery, was far from secure by the mid-1960s. Both government officials and frozen fish company owners became alarmed at the lack of interest on the part of young men in the offshore fishery. The labour shortage became more acute after the federal government introduced the Fisheries Development Act in 1966, which provided assistance on a greater scale for companies needing to acquire trawlers. In fact, increasing Canada's trawler fleet became a major emphasis of federal policy as a response to the growing numbers of foreign vessels fishing off the shores of Newfoundland and Nova Scotia. In an attempt to encourage young men to fill the deepsea fishery courses at the Newfoundland College of Fisheries, government and industry joined forces. ${ }^{40}$ The provincial government quickly organized the Special Committee to Plan Emergency Action on Manpower Training for the Fishing Industry. This committee estimated the numbers of future workers needed in the industry and began organizing "crash courses" for trawler crews at the College of Fisheries. As well, the Newfoundland Frozen Fish Trades Association submitted formal briefs to both the Royal Commission on Education and Youth, and to the provincial government

${ }^{38}$ PANL, MG 644, file 340, “A Brief Concerning National Fisheries Development Program Submitted to the Federal-Provincial Conference on Fisheries Development by the Fisheries Council of Canada - Appendix I, The Frozen Fish Trades Association Limited, St. John's, Newfoundland," 20 January 1964.

${ }^{39}$ Fisheries Research Group, The Social Impact, 174.

${ }^{40}$ PANL, GN 34/2, file NFDA Manpower Training, W. F. Compton, President, College of Fisheries to E. Harvey, NFFTA, 19 February 1966. 
endorsing the "crash course" programme. ${ }^{41}$ In fact, the frozen fish company owners suggested that training programmes be held in Burin because, as they said, "the young people of the south coast are ... traditionally deepsea minded." Several hundred young men went through the programme over the next few years. ${ }^{42}$ Gradually the total number of trawlers increased from 36 vessels in 1963 employing 480 men to 64 vessels in 1972 employing 1300 men, yet high turnover rates for the trawler crews continued. ${ }^{43}$

The turning point for the offshore fishery came in the 1974-1975 season, when the newly-unionized trawler crews staged a strike for union recognition, and to overturn the "co-adventurer" status. ${ }^{44}$ According to Leslie Harris, chair of the Board of Conciliation tasked with resolving this issue, fish landings had been declining as a result of intensive foreign fishing, exacerbating the problem of low earnings, when the earning of the trawler workers was dependent on the size of the catch. ${ }^{45}$ Harris made the argument that trawler workers deserved to be treated in a similar manner to skilled labourers. He argued that trawler workers were akin to working class labourers, but without the comforts and security of a guaranteed wage. Harris also claimed that trawler work needed to be "professionalized," elevated to the level of a skilled tradesmen. With higher incomes that reflected the "skill" of the worker, and the danger and discomfort of deepsea fishing, the problem of encouraging young men to join the trawler fleets would be alleviated. The companies, finally agreed to provide a degree of security in the incomes of trawler workers. Other workplace innovations were instituted, such as the improved safety and working conditions on the vessels. These changes, together with the shortage of work in other parts of the country, contributed to the gradual stabilization of the trawler crews for the offshore fishery.

Although the working condition and remuneration of trawler workers improved, there was never a move to "professionalize," or recognize the "skills" of female processing plant workers. The move to improve incomes and working

${ }^{41}$ Centre for Newfoundland Studies Archives, Memorial University of Newfoundland, J.R. Smallwood Papers, file 3.12.047, "Brief - Hon. J.R. Smallwood, Premier of Newfoundland - Manpower Requirements - Deepsea Trawlers and Shore Processing Plants," by E. A. Harvey, Frozen Fish Trades Association, February 1966; "Brief by the Frozen Fish Trades Association Limited to the Royal Commission on Education and Youth," 1 March 1966.

${ }^{42}$ PANL, GN 34/2, file NFDA Fisheries College 1963-1970, Cyril Banikhin, Director of Administration, College of Fisheries to Ross Young, 19 March 1968.

${ }^{43}$ Fisheries Research Group, The Social Impact, 171-204.

${ }^{44}$ For background on the trawler strike, see David Macdonald, Power Begins at the Cod End: The Newfoundland Trawlerman's Strike, 1974-75 (St. John's 1980).

${ }^{45}$ Leslie Harris, Report of the Conciliation Board appointed in the matter of the Fishing Industry (collective bargaining) Act and in the matter of a dispute between Newfoundland Fishery, Food and Allied Workers, Local 465 and B.C. Packers Ltd., Atlantic Fish, Division of Consolidated Foods Ltd., National Sea Products Ltd., Fishery Products Ltd., and Booth Fisheries (St. John's 1974), 28-53. 
conditions of trawler workers was a gendered process, as ideas about skill, and the needs of a family breadwinner were wound into it. The only major concession that female fish plant workers received was that in the early 1970s, the Newfoundland government rescinded the law which permitted female workers to be paid a lower minimum wage than males.

\section{Conclusion}

THE TRANSITION from saltfish to frozen fish, from a household economy to something resembling a North American consumer industrial society forever altered the lives of the fishing people of Newfoundland. The expanding scale and scope of state intervention in the fishery in the post-war era also played a significant role in shaping the possibilities open to men and women. Fisheries planners brought with them their assumptions about gender roles inherent in the dominant gender ideologies of mainstream North American culture. In fact, they tried to create a new workforce, a new working class for the modernized Newfoundland fishery - a fishery characterized by centralized, vertically integrated frozen fish companies and the latest technological equipment for harvesting and processing. They envisioned the new fishery worker, first and foremost as male, the sole family breadwinner, trained in technological skills needed for the industrialized fishery. With his increased efficiency and productivity, the family breadwinner would presumably earn enough money so that his wife and children would no longer have to contribute to the production of saltfish for market.

The government fishery officials' plans for a new fishery workforce, however, did not go entirely as expected. The anticipated flood of young men into the offshore sector did not materialize. Only after wages stabilized and working conditions improved did working on a trawler appeal to people in Newfoundland. Visions of women being "freed" to follow domestic pursuits while their husbands laboured to bring home the family income never quite materialized either, as many women took jobs as trimmers and packers in the frozen fish processing plants. The legacy of state intervention and the gender ideology that was a part of it, however, has remained, and become embedded in the complex relationship of economy, society, and the Newfoundland fishery.

An earlier version of this paper was presented at the 18th International Congress of Historical Sciences in Montréal, August 28, 1995, as part of the round table session, "Male Identities and the Working Class in Canada and Great Britain since 1870. "I am grateful to Valerie Burton who organized the session and has provided considerable assistance to me during the revision of this article. I would also like to thank those who made useful comments on earlier versions of this paper, including Greg Kealey, Veronica Strong-Boag, and the reviewers of Labour/Le Travail. I received financial assistance for this research from the Social Sciences 


\section{Cambridge Journals}

International Review of Social History

International Review of Social History the oldest scholarly journal of irs kind, is distinguished for the quality, depth and originality of its articles. It also publishes documents, debates, a major bibliography of social studies titles, professionial neurs and an annual supplement of specially commissioned essays on a current ropic, for example, 'The Rise and Decline of the Male Breadwinner Family' (1997).

\section{Recent articles include:}

Productive clerks; white collar Productivism;

Labour Market, work mentality and syndicalism; Dock labour in the Unired States and Hamburg 1900-1950's.
Subscriptions

Volume 43 in 1998: April, August and

Decernber. plus one supplement in December $£ 68$ for institution; $£ 40$ for individuals; $£ 33$ for members of ASA AHA and APSA.

ISSN 0020-8590

\section{Take a closer look... free}

Please send me a free sample copy of International

Review of Social History

name

address

\section{Send coupon to}

Jounais Marketing. Cambridge University Press. The Edinburgh Building Cambridge, CB2 2RU, UK 53593 53593

to contact the Journals Marketing Department-

in Cambridge: tel +44(0)1223325806 fax +44(0)1223 315052 email journals_marketingecup.cam.ac.uk in New York: tel (914) $9379600 \times 154$ fax (914) 9374712 email journals_marketingecup.org
7. CAMBRIDGE 8 UNIVERSIIY PRESS
The Edinburgh Building, Cambridge, $\mathrm{CB}_{2} 2 \mathrm{RV}, \mathrm{UK}$ to West 20th Strect. New York, NY tool1-4211, USA 